\title{
STRATEGI INTERNALISASI NILAI-NILAI AKHLAK DALAM PERENCANAAN PEMBELAJARAN TEMATIK TERPADU KURIKULUM 2013 DI MADRASAH IBTIDAIYYAH
}

Robi'ah Ummi Kulsum (Widyaiswara Ahli Madya Balai Diklat Keagamaan Jakarta) email: hanna.umm@gmail.com

\begin{abstract}
ABSTRAK
Dewasa ini pembelajaran tematik terpadu kurikulum 2013 menjadi sebuah kebijakan yang memiliki banyak implikasi, di antaranya adalah implikasi terhadap persiapan dan hasil pembelajaran. Pembelajaran tematik terpadu 2013 merupakan salah satu pendekatan pembelajaran pada Madrasah Ibtidaiyyah yang berbasis aktifitas (meaningfull learning). Beberapa penelitian membuktikan bahwa pembelajaran tematik mampu meningkatkan motivasi belajar peserta didik. Seolah memberi sinyal positif, di balik persiapan, proses dan evaluasinya yang nampak rumit, pembelajaran tematik terpadu ditengarai sebagai pendekatan yang strategis untuk menginternalisasikan nilai-nilai akhlak.

Dengan menggunakan metode deskriptif kualitatif, penulis hendak memaparkan gambaran secara sistematis, faktual dan akurat tentang strategi menginternalisasikan nilai-nilai akhlak dalam perencanaan pembelajaran tematik terpadu di madrasah ibtidaiyyah.

Hasil yang diperoleh adalah bahwa guna menginternalisasikan nilai-nilai akhlak dalam pembelajaran tematik terpadu memerlukan persiapan. Terdapat dua macam perencanaan bagi guru Madrasah, yaitu perencanaan umum dan perencanaan khusus. Perencanaan umum dilakukan oleh segenap pihak civitas madrasah, sedangkan perencanaan khusus dilakukan oleh pihak guru kelas sebagai fasilitator pembelajaran tematik terpadu. Proses internalisasi nilai-nilai akhlak dalam pembelajaran tematik terpadu melewati tiga tahapan, yaitu transformasi nilai, transaksi nilai dan transinternalisasi nilai. Terdapat faktor penting dalam pelaksanaan pendidikan nilai akhlak, antara lain: guru sebagai teladan, situasi dan kegiatan yang terprogram, dan desain program pendidikan nilai akhlak. Sebagai pengembangan upaya internalisasi nilainilai akhlak dalam pembelajaran tematik terpadu diperlukan desain program pendidikan
\end{abstract}


nilai akhlak di madrasah, yaitu desain pendidikan akhlak berbasis kelas, berbasis kultur madrasah, dan berbasis komunitas.

Kata kunci: perencanaan pembelajaran, tematik terpadu, internalisasi nilai-nilai akhlak.

\section{A. Pendahuluan}

\section{Latar belakang}

Dewasa ini pembelajaran tematik terpadu kurikulum 2013 menjadi sebuah kebijakan yang memiliki banyak implikasi, di antaranya adalah implikasi terhadap persiapan dan hasil pembelajaran. Dampak persiapan pembelajaran yang baik akan membuahkan proses belajar yang menyenangkan dan meningkatkan motivasi belajar peserta didik. Beberapa penelitian tentang implementasi pembelajaran tematik terpadu di beberapa daerah, menunjukkan hasil yang signifikan.

Sebut saja penelitian yang dilakukan oleh Anggitiyas Sekarinasih pada MIN Tempel Sleman Yogyakarta, bahwa hasil implementasi pembelajaran tematik terpadu kurikulum 2013 meningkatkan hasil belajar peserta didik baik dari aspek sikap, pengetahuan maupun keterampilan (Sekarinasih, 2015, p. 108).

Hasil penelitian lainnya, Lutfiana pada siswa kelas V SD se-kota Yogyakarta pada tahun 2015, menunjukkan implementasi pembelajaran tematik terpadu kurikulum 2013 memberi pengaruh sebesar 22.9\% terhadap motivasi belajar peserta didik dari faktor-faktor lainnya (Lutfiana, 2015, p. 78). Hal ini dapat menjadi sinyal positif yang memperkuat motivasi guru untuk dapat mengimplementasikan pembelajaran tematik terpadu kurikulum 2013.

Di sisi lainnya, pembelajaran tematik terpadu menjadi tantangan tersendiri bagi guru Madrasah Ibtidaiyyah karena merupakan pembelajaran yang memiliki karakteristik khas, yaitu memadukan kompetensi beberapa bidang studi dalam satu tema dan berbasis aktifitas (meaningfull learning). Tak jarang guru mengeluhkan akan sulitnya mengimplementasikan pembelajaran tematik terpadu, salah satunya adalah perlunya persiapan yang matang dalam pembelajaran.

Kurikulum 2013 memiliki kompetensi inti yang harus dikuasai oleh siswa yaitu kompetensi sikap, yang selanjutnya dibagi menjadi kompetensi sikap spiritual dan sikap sosial. Hal ini difahami sebagai wujud penyeimbangan keberadaan manusia sebagai makhluk Tuhan dan makhluk sosial. 
Dalam membangun pendidikan Islami yang bermutu, al-Qur'an mengisyaratkan unsur perencanaan sebagai salah satu strategi dalam mencapai tujuan, pada surat al-Hasyr ayat 18 , sebagai berikut:

"Hai orang-orang yang beriman, bertakwalah kepada Allah dan hendaklah setiap diri memperhatikan apa yang telah diperbuatnya untuk hari esok (akhirat); dan bertakwalah kepada Allah, Sesungguhnya Allah Maha mengetahui apa yang kamu kerjakan."

Ditegaskan tentang perencanaan, Rasulullah Saw mengajarkan keutamaan perbuatan adalah dari niat pelakunya, dan yang paling utama niat adalah melakukan perbuatan karena Allah dan rasul-Nya (HR. Buhkari Muslim).

Perencanaan menjadi proses intelektual yang menentukan secara sadar tindakan yang akan ditempuh dan mempertimbangkan informasi, prediksi serta keputusan dalam mencapai tujuan yang ditetapkan. Imam Ali bin Abi Thalib R.A menegaskan bahwa "Kebaikan yang tidak terorganisir akan mampu dikalahkan oleh kejahatan yang terorganisir".

Begitupula dengan pembelajaran, yang merupakan proses transformasi pengetahuan secara terencana dari guru kepada peserta didiknya, tentu saja harus disertai dengan rencana yang tersusun secara sistematis dan terarah dalam mencapai tujuan. Perencanaan ini dikenal dengan perencanaan pembelajaran.

Perencanaan pembelajaran mengandung dua pemikiran utama, yaitu proses pengambilan keputusan dan pengetahuan professional tentang proses pengajaran. (Majid, Perencanaan Pembelajaran, 2008) Perencanaan pembelajaran tidak hanya dilakukan oleh guru, tetapi juga melibatkan unsur lain, seperti kepala madrasah, manajemen madrasah, komite madrasah, dan lainnya.

Keberhasilan perencanaan pembelajaran tematik terpadu menjadi salah satu indikasi dalam pencapaian keberhasilan implementasi pembelajaran tematik terpadu kurikulum 2013. Faisal dalam penelitiannya mengungkapkan keberhasilan pelaksanaan pembelajaran tematik terpadu kurikulum 2013 di SD Kab. Pasaman Barat telah terbilang baik jika ditinjau dari sisi perencanaannya dengan rata-rata nilai 74,8 (Faisal, 2015).

Madrasah Ibtidaiyyah sebagai lembaga pendidikan dasar formal di bawah naungan Kementerian Agama dituntut untuk memiliki output dan outcome yang 
berbeda dari pendidikan formal umumnya. Ekspektasi ini ditambah dengan banyaknya kasus menurunnya moral dasar siswa madrasah maupun tantangan globalisasi yang nyata. Di sisi lain, tuntutan memenuhi standar pendidikan nasional tetap menjadi muatan utama. Guru Madrasah Ibtidaiyyah memiliki tugas yang cukup menantang yaitu menjalankan pembelajaran tematik terpadu, tetapi juga tetap harus menanamkan nilai-nilai akhlak pada diri peserta didik sebagai muatan positif di lingkungan madrasah.

Internalisasi nilai-nilai akhlak merupakan upaya untuk mewujudkan terjadinya proses internalisasi nilai-nilai akhlak pada diri siswa, sehingga berpengaruh terhadap tingkah laku siswa. Nilai-nilai akhlak yang diajarkan dalam agama Islam menuntun manusia hidup selamat dan bahagia di dunia dan akhirat.

Hal inilah yang menjadi tantangan tersendiri bagi guru-guru Madrasah Ibtidaiyyah dalam memahami konsep pembelajaran tematik terpadu, tidak hanya dalam mengintegrasikan pengetahuan dan keterampilan, akan tetapi juga dalam menginternalisasikan nilai-nilai akhlak pada aktifitas pembelajaran.

\section{Identifikasi Permasalahan}

Dari latar belakang di atas, diperoleh permasalahan sebagai berikut:

a. Bagaimana persiapan pembelajaran tematik terpadu kurikulum 2013?

b. Bagaimana guru Madrasah Ibtidaiyyah memahami internalisasi nilai-nilai akhlak dalam pembelajaran tematik terpadu kurikulum 2013?

c. Bagaimana strategi menginternalisasi nilai-nilai akhlak dalam perencanaan pembelajaran tematik terpadu kurikulum 2013 ?

\section{Perumusan Masalah}

"Bagaimanakah strategi menginternalisasi nilai-nilai akhlak dalam perencanaan pembelajaran tematik terpadu kurikulum 2013?"

\section{Tujuan Penelitian}

Penelitian dilakukan untuk mengetahui strategi perencanaan pembelajaran tematik terpadu kurikulum 2013 dalam menginternalisasi nilai-nilai akhlak.

\section{Metodologi Penelitian}


Penelitian ini merupakan studi lanjutan dari penelitian tentang upaya internalisasi nilai-nilai akhlak melalui pembelajaran tematik terpadu di Sekolah Alam Bogor.

Penelitian bersifat deskriptif kualitatif yang bertujuan memaparkan gambaran secara sistematis, faktual dan akurat tentang urgensi perencanaan terhadap upaya internalisasi nilai-nilai akhlak dalam pembelajaran tematik terpadu di madrasah ibtidaiyyah.

\section{B. Kajian Pustaka}

\section{Perencanaan Pembelajaran Tematik Terpadu Kurikulum 2013}

Pembelajaran tematik terpadu dalam kurikulum 2013 merupakan langkah pengembangan dari implementasi pembelajaran tematik pada kurikulum sebelumnya (KTSP). Pembelajaran tematik terpadu yang diterapkan di jenjang Sekolah Dasar dalam kurikulum 2013 berlandaskan pada Permendikbud Nomor 65 Tahun 2013 tentang Standar Proses Pendidikan Dasar dan Menengah yang menyebutkan, bahwa "Sesuai dengan Standar Kompetensi Lulusan dan Standar Isi, maka prinsip pembelajaran yang digunakan dari pembelajaran parsial menuju pembelajaran terpadu."

Pelaksanaan Kurikulum 2013 pada SD/MI dilakukan melalui pembelajaran dengan pendekatan tematik-terpadu dari Kelas I sampai Kelas VI. Di dalam Kurikulum 2013 pendekatan pembelajaran menggunakan pendekatan tematik terpadu dan pendekatan saintifik. Strategi pada pembelajaran tematik terpadu adalah pembelajaran peserta didik aktif. Model pembelajaran tematik terpadu menggunakan model jaring laba-laba. Metode yang digunakan berupa metode proyek yang pembelajarannya dilakukan di dalam atau di luar ruang kelas yang melibatkan peserta didik untuk melakukan kegiatan yang mengintegrasikan berbagai kompetensi dan mata pelajaran. Kegiatan tersebut harus melibatkan berbagai keterampilan seperti keterampilan fisik, intelektual dan juga mata pelajaran beserta kompetensinya yang mencakup sikap, pengetahuan dan keterampilan.

Pada tataran implementasinya pembelajaran terpadu dilaksanakan dalam tiga tahap, yaitu pembukaan, inti dan penutup. Sebagai sentra kegiatan tematik, maka pada kegiatan inti dilaksanakan pembelajaran dengan menerapkan pendekatan 
ilmiah yang meliputi kegiatan mengamati, menanya, mencoba/mengumpulkan data, menalar/mengasosiasi, dan mengkomunikasikan.

Tentu saja implementasi ini tidak dapat berjalan dengan baik tanpa adanya berbagai persiapan yang dilakukan sebelum pembelajaran tematik terpadu dilaksanakan. Persiapan ini meliputi persiapan umum dan khusus.

Persiapan umum dilakukan oleh segenap guru maupun kepala madrasah, sedangkan persiapan khusus adalah persiapan terkait dengan perencanaan pembelajaran tematik terpadu oleh guru dalam implementasi kurikulum 2013.

Adapun persiapan umum meliputi kegiatan mengikuti sosialisasi dan workshop kurikulum 2013, komunikasi dengan warga madrasah, sosialisasi kepada wali murid, dan pengadaan buku ajar. Sebagai suatu kebijakan pendidikan dasar baru, paradigma terhadap pembelajaran harus diubah. Hal ini membutuhkan kesiapan dan pemahaman dari segenap pihak civitas Madrasah Ibtidaiyyah. Untuk itu, pihak manajemen menentukan waktu pertemuan khusus untuk mengkomunikasikan sistem pembelajaran tematik terpadu, dari tujuan pembelajaran hingga evaluasi dan pelaporannya. Begitupula dengan nilai-nilai lembaga termasuk visi misi madrasah yang berkaitan dengan sistem pembelajaran tematik tersebut.

Adapun persiapan pembelajaran khusus yang dilakukan oleh guru, maka diperlukan wawasan yang lebih luas serta pemahaman yang komprehensif terhadap sistem pembelajaran tematik terpadu ini. Guru perlu menyiapkan berbagai kegiatan yang sesuai dengan karakteristik anak usia SD. Pada usia ini, peserta didik mengalami pertumbuhan dan perkembangan fisik dan motorik yang lebih signifikan.

Guru mengarahkan pembelajaran tematik terpadu sesuai dengan aturan pemerintah yang tertuang dalam Permendikbud No. 22 Tahun 2016 tentang Standar Proses Pendidikan Dasar dan Menengah yaitu persiapan dirancang dalam bentuk silabus dan RPP, di mana perencanaan pembelajaran tersebut meliputi penyusunan rencana pelaksanaan pembelajaran, penyiapan media dan sumber belajar, perangkat penilaian pembelajaran, dan skenario pembelajaran.

Hidayat dalam Abdul Majid mengemukakan bahwa perangkat yang harus dipersiapkan dalam perencanaan pembelajaran antara lain memahami kurikulum, menguasai bahan ajar, menyusun program pengajaran dan menilai program 
pengajaran dan hasil proses belajar mengajar yang telah dilaksanakan. (Majid, Perencanaan Pembelajaran, 2008, p. 7)

Pembelajaran tematik terpadu dapat menggunakan beberapa model pembelajaran yang dikembangkan, seperti Model Pembelajaran Langsung, Model Pembelajaran Kooperatif, Pembelajaran Kontekstual, Model Pembelajaran Penemuan Terbimbing, dan Problem Based Learning.

Selain media, alat dan sumber belajar yang perlu diperhatikan oleh guru, pada implementasi Kurikulum 2013 ini pemerintah telah menyiapkan buku teks untuk peserta didik yang dilengkapi dengan buku guru. Materi dalam buku yang tersedia bersifat minimal, jika dalam pemanfaatan memerlukan pengembangan, guru dapat menambahkannya disesuaikan dengan kebutuhan dan karakteristik madrasah dan daerah.

Beberapa langkah perencanaan antara lain pemetaan Kompetensi Dasar, menetapkan jaringan tema, penyusunan silabus pembelajaran tematik dan penyusunan RPP pembelajaran tematik.

a. Pemetaan Kompetensi Dasar

Kegiatan pemetaan ini dilakukan untuk memperoleh gambaran secara menyeluruh dan utuh semua Kompetensi Inti dan Kompetensi Dasar, dan indikator dari berbagai mata pelajaran yang dipadukan dalam tema yang dipilih.

b. Menetapkan jaringan tema

Pembuatan jaringan tema dilakukan dengan cara menghubungkan Kompetensi Dasar dan indikator dengan tema pemersatu. Dengan jaringan tema tersebut akan terlihat kaitan antara tema, Kompetensi Dasar dan indikator dari setiap mata pelajaran. Jaringan tema ini dapat dikembangkan sesuai dengan alokasi waktu yang tersedia untuk setiap tema.

c. Penyusunan silabus pembelajaran tematik

Hasil seluruh proses yang dilakukan pada tahap-tahap sebelumnya dijadikan dasar dalam penyusunan silabus. Komponen silabus terdiri dari:

Identitas mata pelajaran, Identitas madrasah, Kompetensi inti, Kompetensi Dasar, tema, materi pokok, pembelajaran, penilaian, alokasi waktu dan sumber belajar.

d. Penyusunan RPP pembelajaran tematik 
Untuk keperluan pelaksanaan pembelajaran, guru perlu menyusun Rencana Pelaksanaan Pembelajaran (RPP). RPP ini merupakan realisasi yang telah ditetapkan dalam silabus pembelajaran.

Dari uraian di atas, nampak faktor perencanaan pembelajaran tematik terpadu kurikulum 2013 memegang peranan yang signifikan. Pemahaman akan desain pembelajaran tematik terpadu ini amat penting, di mana di dalamnya mencakup alur perencanaan tematik terpadu. Hal ini memerlukan kesiapan baik dari pihak manajemen madrasah, guru kelas maupun guru bidang studi.

\section{Internalisasi Nilai-nilai Akhlak dalam Perencanaan Pembelajaran}

Bagi pembelajaran di madrasah, istilah pendidikan akhlak lebih sesuai daripada menggunakan istilah pendidikan karakter, karena pendidikan akhlak merupakan bagian integral dan tidak terpisahkan dari ajaran Islam. Ia ditujukan untuk mengarahkan potensi-potensi baik yang ada pada diri manusia agar selaras dengan fitrahnya, dan meminimalisir aspek-aspek buruknya. Islam melakukan pendidikan akhlak berdiri pada azas akidah Islamiyyah yang selalu dihubungkan dengan keimanan dan tingkah laku (Ulwan, 2007, p. 193).

Akhlak di dalam kamus Munjid berbentuk kata khuluqu diartikan sebagai tabiat, budi pekerti, perangai, adat atau kebiasaan (Ma'luf, 1976, p. 94). Kata akhlak setelah masuk ke dalam bahasa Indonesia dimaknai sebagai tingkah laku seseorang yang didorong oleh suatu keinginan secara sadar untuk melakukan suatu perbuatan yang baik (Muda, 2006, p. 45). Sedangkan Imam Ghazali dalam kitab Ihya' 'Ulûm al-Dîn menyatakan bahwa akhlak adalah sifat yang tertanam dalam jiwa yang menimbulkan perbuatan-perbuatan dengan mudah tanpa memerlukan pemikiran dan pertimbangan (Abu Hamid, TT, p. 53).

Jadi, esensi pendidikan akhlak sendiri adalah melahirkan manusia yang berkepribadian muslim yang taat terhadap hukum dan ketetapan syari'at Islam, sebagaimana pemahaman tentang akhlak di atas, bahwa sikap taat terhadap syari'at dilakukan tanpa memerlukan banyak pertimbangan atau alasan untuk tidak melaksanakannya.

Rasulullah Saw menyatakan bahwa manusia diciptakan dalam keadaan fitrah atau suci. Hal ini sejalan dengan prinsip akhlak Islam yang benar-benar memelihara eksistensi manusia sebagai makhluk terhormat sesuai fitrahnya. Potensi kebaikan dan keburukan berada pada fitrah manusia tersebut (QS. ar-Rûm (30):30; QS al- 
Syams (91):7-10). Segala sesuatu yang dianggap baik oleh fitrah dan akal yang lurus, ia termasuk bagian dari akhlak yang baik. Sebaliknya, jika dinilai jelek maka akan menjadi bagian dari akhlak yang buruk (R., 2014, p. 157).

Usia dini merupakan usia yang potensial untuk ditanamkan nilai-nilai akhlak, karena potensi fitrah yang dibawa sejak lahir kemudian diarahkan dengan dan kepada nilai-nilai kebaikan sesuai ajaran Islam. Dalam hal ini Marzano (1985) dan Bruner (1960) menyatakan bahwa pada jenjang Madrasah Dasar, ranah attitude harus lebih banyak atau lebih dominan dikenalkan, diajarkan dan atau dicontohkan pada anak, kemudian diikuti ranah skill, dan ranah knowledge lebih sedikit diajarkan pada anak. Hal ini berbanding terbalik dengan membangun soft skills dan hard skills pada jenjang Perguruan Tinggi di mana pada jenjang ini ranah knowledge lebih dominan diajarkan dibandingkan ranah skills dan attitude (Kemendikbud, 2014).

Hal ini menegaskan bahwa pendidikan di Madrasah Ibtidaiyyah merupakan jenjang yang strategis dalam menginternalisasikan nilai-nilai akhlak yang dilakukan melalui berbagai metode yang beragam. Armai Arief menyatakan bahwa metode mengandung arti adanya urutan kerja yang terencana, sistematis dan merupakan hasil eksperimen ilmiah guna mencapai tujuan yang telah direncanakan (Arief, 2002, p. 87).

Menurut an-Nahlawy dalam Ahmad Tafsir menyebutkan tujuh metode penanaman nilai-nilai akhlak melalui pengajaran, yaitu metode hiwar (percakapan/dialog), kisah, dan Amtsal (Perumpamaan) Qur'ani dan Nabawi, keteladanan, pembiasaan, 'Ibrah dan Mau'izah serta Targhib dan Tarhib. Selain tujuh metode tersebut, Ahmad Tafsir menambahkan beberapa metode yang khas dalam menanamkan rasa keberagamaan dalam diri anak, yaitu metode pepujian dan metode wirid (zikrullah) (Tafsir, 2013, pp. 203-208).

Beberapa metode di atas bertujuan agar siswa mengalami kegiatan pembelajaran sendiri dalam lingkungan yang alamiah. Guru secara sabar membimbing siswa dalam berinteraksi, untuk menggali nilai-nilai dari perilaku dalam ajaran Islam yang akan atau telah dilakukan siswa. Siswa secara perlahan membuka dirinya untuk memperbaiki diri dan menerima kebenaran-kebenaran ajaran Islam dalam perilaku keseharian sebagai seorang muslim.

Interaksi yang positif ini didukung oleh sarana, bahan dan alat yang diperlukan. Begitu pula dengan sumber belajar yang ada di lingkungan sekitar 
siswa menjadi learning resources by utilization, seperti orang tua siswa, keluarga, masyarakat sekitar, dan sebagainya. Hal ini mendukung terbentuknya komunitas belajar yang saling menasihati dan saling memberi teladan.

Internalisasi merupakan upaya yang dilakukan untuk memasukkan nilai-nilai kedalam jiwa sehingga menjadi milik seseorang (Ihsan, 1997, p. 155). Internalisasi merupakan suatu proses yang harus terjadi dalam pendidikan. Internalisasi bukan hanya sekedar transformasi ilmu pengetahuan oleh pendidik kepada peserta didik, tetapi menekankan kepada penghayatan serta pengaktualisasian ilmu pengetahuan khususnya ilmu pengetahuan yang berupa nilai sehingga nilai tersebut menjadi kepribadian dan prinsip dalam hidupnya.

Internalisasi nilai menjadi upaya menghayati dan mendalami nilai, agar nilai tersebut tertanam dalam diri setiap manusia. Internalisasi lebih ke arah pertumbuhan batiniah atau rohaniah peserta didik. Pertumbuhan itu terjadi ketika siswa menyadari suatu "nilai/value" yang terkandung dalam pengajaran agama dan kemudian nilai-nilai itu dijadikan sebuah "sistem nilai diri" sehingga menuntun segenap pernyataan sikap, tingkah laku, dan perbuatan moralnya dalam menjalani kehidupan ini.

Jadi, internalisasi nilai-nilai akhlak tepatnya disampaikan menggunakan berbagai metode, diantaranya adalah dengan menggunakan metode Qur'ani dan Nubuwwah di atas. Metode yang paling mendominasi dari berbagai metode di atas adalah metode keteladanan. Untuk itu, faktor keteladanan orang tua, pemerintah, lembaga dan guru menjadi hal paling strategis dalam upaya internalisasi nilai-nilai akhlak tersebut.

\section{Hasil dan Pembahasan}

Merupakan bagian dari tindakan profesional guru adalah menyiapkan beberapa aktivitas dalam proses perencanaan, diantaranya adalah memberikan motivasi dan implementasi program. (Majid, Perencanaan Pembelajaran, 2008) Pada tahap ini guru mempersiapkan teknik motivasional yang akan diterapkan dan beberapa prosedur administratif yang perlu diikuti agar aktifitas dalam rencana pengajaran berjalan dengan baik.

Tentu saja hal ini tidak dapat dikesampingkan mengingat tugas guru selain mengajar juga mendidik. Sebagai pendidik, guru memfasilitasi pembelajaran agar 
tidak hanya mentransfer pengetahuan tetapi juga menanamkan nilai-nilai budi pekerti atau dikenal dalam Islam dengan sebutan akhlak.

Keberadaan kompetensi inti sikap spiritual (KI I) dan sikap sosial (KI II) hendaknya dimanfaatkan oleh guru madrasah sebagai nilai-nilai yang diarahkan oleh pemerintah sebagai learning values (nilai-nilai pembelajaran). Dengan pedoman akhlak berbasis nilai-nilai al-Qur'an dan Sunnah, tidak diragukan lagi menjadi support bagi internalisasi nilai-nilai akhlak dalam pembelajaran tematik terpadu pada madrasah Ibtidaiyyah.

Dalam menginternalisasikan nilai-nilai akhlak memerlukan beberapa faktor pendukung, antara lain suasana yang religius, pembiasaan serta interaksi belajar mengajar. Agar nilai-nilai tersebut sepenuhnya menjadi bagian sistem kepribadian setiap siswa, maka tahap pengenalan dan pemahaman, penerimaan serta pengintegrasian wajib ditempuh (Soedijarto, 1993).

Pada Madrasah Ibtidaiyyah yang merupakan pendidikan formal, proses penginternalisasian nilai-nilai akhlak diantaranya dapat dilakukan dengan lima cara, yaitu internalisasi nilai-nilai akhlak dengan pengajaran, peneladanan, pembiasaan, pemotivasian (targhib), dan dengan penegakan aturan (tarhib) (Tafsir, 2013). Kelima hal ini menjadi metode yang saling melengkapi dalam proses internalisasi nilai-nilai akhlak dalam pembelajaran tematik terpadu.

Proses internalisasi nilai melewati beberapa tahapan, di antaranya adalah:

a. Tahap transformasi nilai, pada tahap ini guru sekedar menginformasikan nilai-nilai akhlak baik dan akhlak tercela kepada siswa, yang semata-mata merupakan komunikasi verbal.

b. Tahap transaksi nilai, merupakan suatu tahap pendidikan nilai dengan jalan melakukan komunikasi dua arah, atau interaksi antara siswa dan guru bersifat timbal balik. Dalam tahap ini tidak hanya menyajikan informasi tentang nilai yang baik dan yang buruk, tetapi juga terlibat untuk melaksanakan dan memberikan contoh amalan yang nyata, dan siswa diminta memberikan respons yang sama, yakni menerima dan mengamalkan nilai itu. Pada tahap ini, kelima metode internalisasi nilai akhlak di atas sudah lebih aktif dilaksanakan, utamanya metode keteladanan dan pembiasaan.

c. Tahap transinternalisasi, yakni bahwa tahap ini lebih dalam daripada sekedar transaksi. Dalam tahap ini penampilan guru di hadapan siswa bukan 
lagi sosok fisiknya, melainkan sikap mentalnya (kepribadiannya). Demikian juga siswa merespons kepada guru bukan hanya gerakan/penampilan fisiknya, melainkan sikap mental dan kepribadiannya. Oleh karena itu, dapat dikatakan bahwa dalam transinternalisasi ini adalah komunikasi dua kepribadian yang masing-masing terlibat secara aktif (Muhaimin, 2001). Dalam tahap ini, nilai akhlak hadir tanpa paksaan dan menjadi rupa (suluk) bagi performance guru dan siswa sebagai warga madrasah.

Perencanaan pembelajaran memiliki posisi yang strategis dalam menginternalisasikan nilai-nilai akhlak, di mana selain mencantumkan tujuan, proses serta penilaian yang akan diselenggarakan, tetapi juga harus mampu menetapkan nilainilai akhlak yang dibangun melalui aktifitas belajar. Mengingat perkembangan kognitif anak usia SD/MI antara lain senang mengenal dunia yang lebih luas, sedikit berimajinasi, rasa ingin tahu meningkat, mampu beradaptasi dengan beberapa kondisi yang dihadapi, tetapi bermasalah dengan kondisi abstrak, angka-angka yang banyak serta periode waktu dan ruang, maka guru perlu menyiapkan berbagai aktivitas/kegiatan yang sesuai dengan karakteristik tersebut.

Selain itu, keberhasilan pembelajaran tematik terpadu tergantung pula pada lingkungan kelas yang diciptakan yang dapat mendorong peserta didik untuk belajar dan menjadi tempat belajar yang nyaman, aman, dan menyenangkan. Penataan lingkungan kelas bisa berupa pengaturan peserta didik dan ruang kelas. Pengaturan tersebut mencakup pengaturan meja-kursi peserta didik, penataan sumber dan alat bantu belajar, dan penataan pajangan hasil karya peserta didik. Pengorganisasian atau pengaturan peserta didik dapat dilakukan dalam bentuk klasikal, kelompok dan individual.

Dari sini dapat diketahui terdapat hubungan yang erat antara internalisasi nilainilai dengan kurikulum di madrasah, yaitu terdapatnya beberapa faktor yang perlu ditumbuhkembangkan dalam pelaksanaan pendidikan nilai akhlak, antara lain: guru sebagai teladan, situasi dan kegiatan yang terprogram, dan desain program pendidikan nilai akhlak.

Pertama, faktor keteladanan. Dalam implementasi pendidikan nilai akhlak di madrasah, nampak fungsi dan peran guru sangat dominan. Sosok 'The Inspiring teacher' yang menjadi teladan merupakan faktor utama karena ia menjadi model dalam internalisasi nilai tersebut. Guru adalah pelaku perubahan. Kehadiran, sikap, pemikiran, nilai-nilai diri, visi yang dimiliki, serta komitmennya merupakan dimensi 
penting yang secara tidak langsung mengajarkan nilai yang membentuk karakter siswa. Apapun fungsi dan jabatan guru di dalam madrasah, mereka tidak dapat menanggalkan keberadaan diri mereka sebagai agen pendidik akhlak.

Kedua, situasi yang kondusif dan kegiatan-kegiatan terprogram amat diperlukan dalam pendidikan nilai-nilai akhlak. Situasi yang dibentuk oleh madrasah diharapkan dapat memungkinkan siswa untuk menyaksikan dengan mata kepala sendiri, mengetahui dengan pengertian yang benar, serta mengalami sendiri bagaimana nilainilai itu dihayati dan direalisasikan dalam kehidupan sehari-hari.

Kegiatan pembelajaran tematik terpadu merupakan integrasi antarmata pelajaran, dimana aktifitas belajar menjadi "sajian utama" dalam menggabungkan berbagai kompetensi. Aktifitas inilah yang menjadi titik pantulan dalam mencapai tujuan pembelajaran.

Aktifitas pembelajaran dalam kurikulum 2013 lebih menitikberatkan pada pembelajaran bermakna atau meaningfull learning. Karakteristik pembelajaran bermakna adalah aktif, konstruktif, autentik, kooperatif dan terencana. (Weeldreyer, 2015) Untuk itu, aktifitas belajar tematik terpadu mengusung pembelajaran bermakna yang mengambil unsur kontekstual sebagai daya pengikatnya, seperti lingkungan keluarga, lingkungan madrasah, teman bermain, energi sehari-hari, dan sebagainya.

Adapun nilai-nilai akhlak yang hendak ditanamkan dalam pendidikan di Madrasah Ibtidaiyyah hendaknya mengacu pada tujuan pendidikan Islam sendiri, yaitu (1) pembentukan berkepribadian Islami; (2) penguasaan Tsaqofah Islamiyyah; (3) penguasaan sains teknologi dan keahlian yang memadai guna melanjutkan ke jenjang berikutnya (Yusanto, 2004). Di antaranya adalah nilai-nilai tauhidullah dan ubudiyah seperti takwa kepada Allah Swt, malu membuka aurat, selalu memakan makanan halal (sikap spiritual) atau nilai-nilai yang mendukung kekuatan pribadi, ukhuwwah dan pergaulan antar sesama, seperti rajin, bertanggungjawab, mandiri, aktif, kreatif, berpikir rasional, sopan dan cinta tanah air.

Nilai-nilai akhlak yang diharapkan muncul dari proses internalisasi ini sangat berkaitan erat dengan tujuan pendidikan akhlak. Terdapat tiga tingkatan tujuan pendidikan akhlak diberikan sejak dini, yaitu tingkatan pertama adalah bahwa agar anak merasa selalu dilihat Allah Swt; tingkatan selanjutnya adalah agar anak merasa melihat SangPenciptanya; sedang tingkatan berikutnya adalah agar anak merasa telah dekat kepada Rabbnya (Tafsir, 2013). 
Keimanan kepada Allah Swt diharapkan dapat menghiasi diri dengan akhlak mulia, seperti sabar, ikhlas, tawadhu, taat, tawakkal, dan qana'ah. Begitu pula dengan kewaspadaan terhadap hadirnya penyakit hati seperti takabbur, hasud, marah, berbohong dan munafik yang dapat mengganggu rasa keimanan bahkan menghancurkan akhlaknya perlahan-lahan.

Kepribadian yang indah sedikit banyak akan mempengaruhi relasi sosialnya. Meningkatnya rasa persaudaraan (ukhuwah) di antara sesama muslim; taat kepada orang tua, guru dan pemimpin; mengikuti aturan dan hukum yang benar berdasarkan syari'at; memakan makanan halal dan thoyyib; bermu'amalah dengan jujur dan bersih; mencintai keindahan dan membiasakan hidup sehat; serta melayani orang lain dengan berbagai kemudahan, merupakan beberapa contoh nilai akhlak sosial.

Ketiga, faktor desain program pendidikan nilai akhlak di madrasah. Dalam proses menginternalisasikan nilai-nilai akhlak di madrasah, dikenal adanya tiga basis desain dalam pemrogramannya, yaitu desain pendidikan akhlak berbasis kelas, berbasis kultur sekolah, dan berbasis komunitas (Muslich, 2011).

Desain pendidikan akhlak berbasis kelas bertumpu pada relasi guru sebagai pendidik dan siswa sebagai pembelajar. Konteks pendidikan di sini adalah proses relasional komunitas kelas dalam konteks pembelajaran. Relasi ini berupa dialog dengan banyak arah, antara guru dan siswa yang bersama-sama berinteraksi dengan materi.

Memberikan pemahaman dan pengertian akan keutamaan yang benar terjadi dalam konteks pengajaran ini. Tentu saja hal ini melibatkan kemapanan dalam penyusunan rencana pembelajaran, proses pelaksanaan pembelajaran serta penilaian yang tidak dapat dipisahkan dari konsep proses pembelajaran. Selain itu, ranah noninstruksional seperti manajemen kelas, konsensus kelas, dan lain-lain, juga menjadi faktor pendukung pendidikan akhlak berbasis kelas ini hingga pada akhirnya tercipta suasana belajar yang nyaman.

Mengapa pendekatan tematik terpadu menjadi media yang tepat dalam menginternalisasikan nilai-nilai akhlak? Dalam hal ini guru harus menyadari bahwa pembelajaran yang kontekstual, bersumber dari keseharian siswa, dekat dengan apa yang mereka lihat dan dengar sehari-hari menjadi ruang yang nyaman dan memiliki peluang besar dalam memasukkan akhlak Islam ke dalam kepribadian dan keseharian mereka. Untuk itu, desain pendidikan akhlak berbasis kelas harus benar-benar diperhatikan dan difahami oleh setiap guru kelas di Madrasah Ibtidaiyyah, karena ini 
merupakan peluang yang tepat untuk menanamkan akhlak yang baik sesuai tuntunan Qur'an dan Sunnah.

Guru Madrasah Ibtidaiyyah harus mau menyengaja dengan memberikan keteladanan dan pembiasaan di dalam maupun di luar kelas dalam melakukan kebaikan dan memperhatikan adab-adab belajar. Selain itu, perduli lingkungan, hormat dan cinta kepada orang tua dan guru, mentaati aturan kelas, melakukan aktifitas pembelajaran dengan ikhlas dan cermat, bersahabat dan kompak dengan teman sekelas maupun kelas lainnya, dan sebagainya merupakan nilai-nilai dalam keteladanan dan pembiasaan melalui aktifitas pembelajaran tematik terpadu.

Syaratnya guru MI harus memulainya juga dengan pemahaman dan keikhlasan. Pembelajaran tematik terpadu tidak lagi menjadi beban, baik dari proses perencanaan, pelaksanaan maupun evaluasinya, semuanya dijalankan dengan ketulusan dan semangat menebarkan kebaikan. Meski proses pembelajaran tematik terpadu nampak agak rumit, guru MI diharapkan mau dan tekun mempelajari dan terus memahaminya hingga pembelajaran yang lahir di kelas menjadi pembelajaran yang bermakna. Inilah urgensi perencanaan dalam tataran desain pendidikan akhlak berbasis kelas.

Desain pendidikan akhlak berbasis kultur madrasah berupaya membangun kultur madrasah yang mampu membentuk akhlak Islami siswa dengan bantuan pranata sosial di madrasah agar dapat terwujudnya nilai-nilai tertentu hingga terpatri dalam dada serta menjadi habit (kebiasaan) yang baik pada diri siswa. Penyusunan sistem tata aturan madrasah dibentuk secara lurus dan konsisten, yang tidak hanya nampak secara lahiriah, seperti adanya tata tertib maupun sanksi dan hukuman tertulis, tetapi juga ada semacam kesepakatan yang ditaati bersama hingga timbul keengganan untuk melanggar peraturan, kebiasaan baik yang mengkultur, hingga itu dapat diterapkan di luar madrasah. Tentunya hal ini harus melibatkan semua elemen yang ada dalam civitas akademi di lingkungan madrasah tanpa terkecuali.

Tidak kalah pentingnya adalah mengejawantahkan visi misi lembaga MI dalam nilai-nilai akhlak yang dapat diimplementasikan dalam aktifitas harian, sehingga menjadi kultur bagi lembaga tersebut. Selain aktifitas pembelajaran, kegiatan ekstra kurikuler, aktifitas pembiasaan seperti murottal al-Qur'an, upacara bendera, unit kesehatan madrasah, dan lainnya menjadi aktifitas pendukung atas upaya internalisasi nilai-nilai akhlak dalam lembaga. Inilah urgensi perencanaan dalam tataran desain pendidikan akhlak berbasis kultur madrasah. 
Desain terakhir adalah desain pendidikan akhlak berbasis komunitas. Desain ini menjadi salah satu pilar dalam menginternalisasi nilai-nilai akhlak di madrasah. Pendidikan akhlak akan menjadi utuh dan menyeluruh ketika memiliki ikatan dengan komunitas sekitar, baik dalam lingkup lokal maupun internasional.

Harus diakui, tidak semua hal dapat dilakukan madrasah. Kerjasama dengan berbagai pihak dibutuhkan bagi pengembangan pendidikan akhlak di madrasah. Aktifitas outing yang biasanya dilakukan dengan bekerjasama dengan unsur pemerintah, lembaga sosial masyarakat, lembaga dakwah di masyarakat, dan lainnya dilakukan dengan melandaskan nilai-nilai akhlak yang diusung dalam aktifitas tersebut. Misalnya tema outing ke pasar dalam rangka observasi proses berjual beli, maka nilai-nilai akhlak yang hendak dibangun adalah bagaimana adab jual beli dalam Islam. Untuk itulah, desain pendidikan akhlak berbasis komunitas ini menjadi penting bagi manajemen madrasah, guru, dan orang tua selaku pemangku kepentingan agar terbangun komunikasi yang baik dan efektif. Inilah urgensi perencanaan dalam tataran desain pendidikan akhlak berbasis komunitas.

Beberapa hal yang dapat dilakukan oleh guru, lembaga madrasah dan komite untuk melaksanakan perencanaan pembelajaran tematik terpadu dalam menginternalisasikan nilai-nilai akhlak.

Tabel 1. Perencanaan pembelajaran tematik terpadu dalam menginternalisasikan nilainilai akhlak

\begin{tabular}{|l|l|}
\hline Guru Kelas & $\begin{array}{l}\text { 1. Memahami dan melaksanakan secara utuh mekanisme } \\
\text { sistem pembelajaran tematik terpadu, dari perencanaan, } \\
\text { proses dan evaluasi. } \\
\text { 2. Merumuskan aktifitas pembelajaran tematik terpadu } \\
\text { yang dapat memuat nilai-nilai akhlak. } \\
\text { 3. Menetapkan nilai-nilai akhlak tertentu yang akan } \\
\text { dimasukkan dalam aktifitas pembelajaran. } \\
\text { 4. Menjadi teladan yang dapat menginternalisasikan nilai- } \\
\text { nilai akhlak di mana dan kapan saja. } \\
\text { 5. Memelihara aktifitas pembiasaan yang mengandung } \\
\text { nilai-nilai akhlak. }\end{array}$ \\
\hline Manajemen Madrasah & \begin{tabular}{l} 
1. Menetapkan nilai-nilai lembaga/madrasah sesuai visi \\
\hline
\end{tabular}
\end{tabular}




\begin{tabular}{|c|c|}
\hline & $\begin{array}{l}\text { misi madrasah yang berlandaskan akhlak. } \\
\text { 2. Mensosialisasikan nilai-nilai akhlak dalam bentuk } \\
\text { pemberitahuan, tata tertib, spanduk, banner, dan } \\
\text { display kelas kepada seluruh civitas madrasah. } \\
\text { 3. Menentukan tema besar yang berhubungan dengan } \\
\text { nilai-nilai lembaga, seperti kepahlawanan dalam Islam, } \\
\text { para ilmuwan muslim, kota-kota bersejarah dalam } \\
\text { Islam, dan lainnya, yang diharapkan dapat memberikan } \\
\text { spirit dan menjadi teladan bagi peserta didik dan } \\
\text { seluruh civitas madrasah. Hal ini kemudian dapat } \\
\text { ditetapkan menjadi nama-nama kelas, tema kegiatan } \\
\text { tahunan, dan sebagainya. } \\
\text { 4. Mengawasi dan mengontrol penetapan nilai-nilai } \\
\text { akhlak tadi di dalam aktifitas pembelajaran intra } \\
\text { kurikuler, ekstra kurikuler, pembiasaan kelas, maupun } \\
\text { aktifitas non-akademis lainnya. } \\
\text { 5. Menjalin kerjasama dengan network dan menetapkan } \\
\text { nilai-nilai akhlak dalam program-program kerjasama } \\
\text { 6. Merefleksi nilai-nilai akhlak yang tercapai dalam } \\
\text { pelaksanaan program pembelajaran. }\end{array}$ \\
\hline Komite madrasah & $\begin{array}{l}\text { 1. Melakukan kerjasama dan mendukung dalam setiap } \\
\text { aktifitas belajar yang diselenggarakan oleh madrasah. } \\
\text { 2. Memahami nilai-nilai akhlak yang ditetapkan madrasah } \\
\text { dan mendukung penanaman nilai-nilai tersebut di } \\
\text { rumah. } \\
\text { 3. Mendukung serta merekomendasikan network yang } \\
\text { dapat diajak bekerjasama dalam aktifitas belajar. }\end{array}$ \\
\hline
\end{tabular}

Oleh sebab itu, dalam perencanaan pembelajaran tematik terpadu amat penting disusun secara sistematis dan komprehensif, apalagi dalam upaya menginternalisasikan nilai-nilai akhlak.

\section{Simpulan dan Saran}




\section{Simpulan}

Persiapan pembelajaran tematik terpadu kurikulum 2013 bagi guru Madrasah dilakukan melalui dua langkah, yaitu persiapan umum dan persiapan khusus. Persiapan umum dilakukan oleh segenap pihak civitas madrasah. Sedangkan persiapan khusus dilakukan oleh pihak guru kelas sebagai fasilitator pembelajaran tematik terpadu.

Guru MI harus memahami betapa pentingnya internalisasi nilai-nilai akhlak dalam pembelajaran tematik terpadu kurikulum 2013, karena pembelajarannya yang berbasis aktifitas (meaningfull learning). Proses internalisasi nilai ini melewati tahapan transformasi nilai, transaksi nilai dan transinternalisasi nilai. Prosesnya menggunakan berbagai metode untuk menginternalisasikan nilai-nilai akhlak dalam pembelajaran tematik terpadu, yaitu dilakukan dengan pengajaran, keteladanan, pembiasaan, penegakan aturan dan pemberian motivasi.

Guru MI dapat melihat hubungan yang erat antara internalisasi nilai-nilai dengan kurikulum di madrasah, yaitu terdapatnya faktor penting dalam pelaksanaan pendidikan nilai akhlak, antara lain: guru sebagai teladan, situasi dan kegiatan yang terprogram, dan desain program pendidikan nilai akhlak. Sebagai pengembangan upaya internalisasi nilai-nilai akhlak dalam pembelajaran tematik terpadu diperlukan desain program pendidikan nilai akhlak di madrasah, yaitu desain pendidikan akhlak berbasis kelas, berbasis kultur madrasah, dan berbasis komunitas.

\section{Saran}

a. Bahwa penting menginternalisasikan nilai-nilai akhlak dalam sebuah grand desain yang terstruktur, untuk itu kepada guru Madrasah Ibtidaiyyah hendaknya memahami dan melaksanakan sistem pembelajaran tematik terpadu secara utuh seraya menginternalisasikan nilai-nilai akhlak di dalam tiap aktifitasnya.

b. Karena pembelajaran tematik terpadu yang utuh memerlukan faktor pendukung yang sistemik, maka lembaga dalam hal ini Madrasah Ibtidaiyyah diharapkan mampu merealisasikan desain program pendidikan akhlak di Madrasah. 


\section{DAFTAR PUSTAKA}

Abu Hamid, M. I.-G. (TT). Ihya 'Ulum al-Din. Beirut: Dar al-Ma'rifah.

Arief, A. (2002). Pengantar Ilmu dan Metodologi Pendidikan Islam. Jakarta: Ciputat Press.

Badri, N., \& Miftah, Z. (2008). Metode Pengajaran dalam Strategi belajar Mengajar dalam Pandangan Islam. Jakarta: UIN Jakarta.

Faisal. (2015, Agustus 29). Diakses Juni 9, 2016, dari faisalpendas.wordpress.com: https://faisalpendas.wordpress.com/2015/08/29/potret-efektivitas-pembelajaran-tematikterpadu-dalam-implementasi-kurikulum-2013-di-sd-kabupaten-pasaman-barat/

Ihsan, F. (1997). Dasar-dasar Kependidikan. Jakarta: Rineka Cipta.

Kemendikbud. (2014). Materi Pelatihan Guru Implementasi Kurikulum 2013 Tahun Ajaran 2014/2015 Mata Pelajaran IPA SMP/MTs. Jakarta: BPSDM Pendidikan dan Kebudayaan dan PMP Kemendikbud.

Lutfiana. (2015, Agustus). Diakses Juni 9, 2016, dari eprints.uny.ac.id: http://www.eprints.uny.ac.id/25081/1/SKRIPSI_LUTFIANA_11108244084.pdf

Majid, A. (2008). Perencanaan Pembelajaran. Bandung: Remaja Rosdakarya.

Majid, A. (2008). Perencanaan Pembelajaran: Mengembangkan Standar Kompetensi Guru.

Bandung: Remaja Rosdakarya.

Ma'luf, L. (1976). al-Munjid fi al-Lughah wa al-'alam. Beirut: Dar al-Masyriq.

Muda, A. A. (2006). Kamus Lengkap Bahasa Indonesia. Jakarta: Reality Publisher.

Muhaimin. (2001). Paradigma Pendidikan Islam. Bandung: RemajaRosdakarya.

Muslich, M. (2011). Pendidikan Karakter Menjawab Tantangan Krisis Multidimensional. Jakarta: Bumi Aksara.

R., M. D. (2014). Pendidikan Akhlak dan Karakter dalam Perspektif Islam dan Barat. Bogor: Pustaka Al-Bustan.

Sekarinasih, A. (2015, Mei). Diakses Juni 9, 2016, dari digilib.uin-suka.ac.id: http://digilib.uinsuka.ac.id/16495/2/11480015_bab-i_iv-atau-v_daftar-pustaka.pdf

Soedijarto. (1993). Menuju Pendidikan Nasional yang Relevan dan Bermutu. Jakarta: Balai Pustaka.

Tafsir, A. (2013). Ilmu Pendidikan Islami. Bandung: Remaja Rosdakarya.

Ulwan, N. (2007). Pendidikan Anak dalam Islam. Jakarta: Pustaka Amani.

Weeldreyer, K. (2015, Juni 10). Diakses Desember 19, 2016, dari Prezi.com: https://prezi.com/rc7v_nvg8oft/5-characteristics-of-meaningful-learning/

Yusanto, M. I. (2004). Menggagas Pendidikan Islami. Jakarta: Al-Azhar Press. 